\title{
The Effects of Intellectual Capital and Institutional Ownerships on the Financial Performance (Empirical Study on the Listed of Banking Companies, the Indonesia Stock Exchange Periods of 2015-2017
}

\author{
Nurhayati $^{1} \quad$ Neti Agustini Hidayah ${ }^{2} \quad$ Kania Nurcholisah $^{2} \quad$ Epi Fitriah $^{2}$ \\ Accounting Department, Economic and Business Faculty, Bandung Islamic University, \\ Jl. Tamansari No.1 Bandung Indonesia
}

\begin{abstract}
The aim of the research is to determine the effects of intellectual capital and institutional ownership on financial performance. The sample used in this study was 45 banking companies listed on the Indonesia Stock Exchange (BEI) period 2015-2017 . Based on the sample and the observations, 122 observational data were obtained . The type of data used by researchers is secondary data obtained from the annual financial statements of banks listed on the Indonesia Stock Exchange taken from www.idx.co.id.The research method used is a research method with a quantitative and descriptive approach.To assess the Hypothesis, the researcher used multiple linear regression analysis that has met the classical assumption test requirements. The results showed that intellectual Capital and institutional ownership have effects on banking financial performance during 2015-2017. Intellectual capital has a significant effect on banking financial performance while institutional ownership is proven to have a non-significant effect on financial performance.
\end{abstract}

DOI: $10.7176 /$ RJFA/11-10-09

Publication date:May $31^{\text {st }} 2020$

\section{A. Introduction}

In the global era,world economy depends on how banks manage their funds to carry out economic rotation in a country.Bank is a business entity that collects public funds in the form of saving and distributing it to the community in the form of credit and or other forms in order to improve the lives of many people according to Law number 10 of 1998 article 1 (Wiroso: 2005: 2).Banks are also used as a driving force for the national economy and also to assess the welfare of the people of a country.Bank performance is analyzed through financial statements that can provide reports on financial conditions for decision making.

In showing the financial performance, it is necessary to make financial statements so that they can be accounted for to the interested parties. The financial statements have the purpose of providing information related to finance, performance and financial position that can be useful and used in making decisions in Statement Accounting Information standards(PSAK) No. 1 the revision version of 1998 (sulistyowati: 2010: 5). Thus, the financial statements of a bank can be used as a third party benchmark to measure the health status of the bank.

The measurement of bank financial performance is closely related to the use of financial statements as theproviders of information. This financial performance is measured using ROA ( Return On Asset) because ROA can help investors and banking parties in evaluating financial performance (Sin hien and Mariani Ida: 2017: 160). The profit will be used by interested parties to assess financial performance.

The status of financial performance of a bank can be viewed through banking financial performance reports that provide information that can be used to attract third parties such as added value from the bank itself. This added value can be in the form of intellectual capital (intellectual capital) which is a combination of intangible assets used to assist in carrying out the business stated by Brooking (ulum ihyaul, 2017; 79). The existence of intellectual capital is difficult to know because it is difficult to measure it.

By managing the economy, it is important for the banks to maintain their survival by trying to gain trust by improving their financial performance. Therefore, internal parties will continue to identify problems arising from their activities by measuring financial performance and making effective decisions.

Internal parties within the Bank will monitor problems that arise within the bank. In addition to the internal parties, the shareholders as those who have institutional ownership must also monitor the manager so that the manager can not make a fraud. Banks must continue to have good performance because there is an institutional oversight thatobserve and will give their trust to the bank so that the bank gets good feedback as well.

Based on the background described, the formulation of the problem are as follows:

1. What are the effects of intellectual capital and financial performance in banks listed on the Indonesia stock exchange?

2. What are the effects of institutional ownership and financial performance in banks listed on the Indonesia stock exchange?

Based on the problem identification, the objectives of the research are: 
1. To find out the effects of intellectual capital and financial performance in the banks listed on Indonesia stock exchange.

2. To find out the effects of institutional ownership and financial performance in banks listed on the Indonesia Stock Exchange.

\section{B.Theoritical Framework \\ 1)Intellectual Capital}

Intellectual capital according to Broking (Ulum Ilhaul: 2017: 79) is a combination of intangible assets, intellectual property, employees, and infrastructure that can help to run a company. In the definition stated by Broking, it can be seen that intellectual capital is not only about human capitalbut also human capital is part of several components listed as intellectual capital.

Another definition of intellectual capital is stated by Stewart (Ulum Ilhaul: 2017: 79) who argues that intellectual capital is all that the owned by a company to help in the market competition. namely intellectual material which consists of knowledge, information, experience and Intellectual property that can used to create prosperity.

With these definitions, it can be concluded that intellectual capital is a combination of all intangible assets owned by companies both intellectual material and intellectual property that can help companies in the completion and carryout good corporate functions.

By having an intellectual Capital builder component, VACA, to see to what extent the net profit or available funds generate a large return by looking at the comparison of value added with employess capital available. VAHU to find out how value added can be generated from the funds spent on the work labors by considering the Comparison between available value added and human capital. STVA, is to find out the amount of money needed to create success in obtaining value.

\section{2) Institutional Ownership}

The high level of institutional ownership shows the high level of supervising by institutional investors to overcomeoperationalattitude of the managers . Institutional ownership in banking acts as a party that monitors which can indicate the company's ability to monitor management (Hery, 2014: 172-173)

Institutional ownership is calculated by comparing the total shares with shares held by the institution. Share holders can also monitor the company performance indirectly.

\section{3) Financial Performance}

According to Jumingan (2006: 239), financial performance is a financial condition used to see to what extent funds and or funds distribution that are usually measured by capital adequacy, liquidity and profitability. Performance of financial is an analysis carried out to look the level a company has implemented the rules of financial implementation properly and correctly (Fahmi Irham: 2011: 2).

The organizational strategy planning proposed by Masun (Nofriansyah Deny. 2018: 19), The description of the level of achievement of an activity is Performance, program, policy in The realizing goals of Policy, objectives, mission and vision contained Therefore, based on these definitions, financial performance is an analysis used to what level a company is able to utilize funds and distribute funds in accordance with the regulations.

Financial performance can be measured by Return On Assets (ROA) which compares the net assets and total assets owned by the company.

\section{Methode}

The method used in this research is a quantitative and descriptive approach. To assess the Hypothesis, the researcher used multiple linear regression analysis that has met the classical assumption test requirements. The sample used in this reseach was 45 banking companies listed on the Indonesia Stock Exchange (BEI) period 2015-2017. Based on the 122 observational data were obtained. The type of data used by researchers is secondary data obtained from the annual financial statements of banks listed on the Indonesia Stock Exchange taken from www.idx.co.id.

\section{Results}

To measure a variable that has a simultaneous effect to each other, simultaneous test is conducted as follows: 
Table 1

F Test

$\operatorname{ANOVA}^{\mathrm{b}}$

\begin{tabular}{|ll|l|l|l|l|l|}
\hline Model & & Sum of Squares & Df & Mean Square & F & Sig. \\
\hline 1 & Regression & .030 & 2 & .015 & 10.628 & $.000^{\mathrm{a}}$ \\
& Residual & .140 & 100 & .001 & & \\
& Total & .169 & 102 & & & \\
\hline
\end{tabular}

a. Predictors: (Constant), intellectual capital, Institutional Ownership

b. Dependent Variable: ROA

The results of the $\mathrm{F}$ test, a significant level is $(0.000<0.05)$. Therefore, it can be concluded that the components of Intellectual capital and institutional ownershiphave effects on the financial performance of the banking companies registered on the Indonesia Stock Exchange period 2015-2017.

The Effects of Intellectual capital and Institutional Ownership on financial Performance

Table 2

T Test

Coefficients $^{\mathrm{a}}$

\begin{tabular}{|c|c|c|c|c|c|c|}
\hline \multirow{2}{*}{\multicolumn{2}{|c|}{ Model }} & \multicolumn{2}{|c|}{ Unstandardized Coefficients } & \multirow{2}{*}{\begin{tabular}{|l} 
Standardized \\
Coefficients
\end{tabular}} & \multirow[b]{2}{*}{$\mathrm{t}$} & \multirow[b]{2}{*}{ Sig. } \\
\hline & & B & Std. Error & & & \\
\hline \multirow[t]{3}{*}{1} & (Constant) & .041 & .020 & & 2.101 & .038 \\
\hline & Institutional Ownership & -.013 & .020 & -.061 & -.662 & .510 \\
\hline & VAICSQ & .044 & .010 & .422 & 4.609 & .000 \\
\hline
\end{tabular}

a. Dependent Variable: ROA

From the results of the t-test, it can be concluded that the effects of the variables on financial performance is as follows:

1. Institutional ownership has an effect on financial performance. However, the effect of ownership is not significant where the significance value is $(0.510>0.05)$ taken from banking dataon the Indonesia Stock Exchange period 2015-2017.

2. Intellectual capital has a significant effect on financial performance where the significance value of the intellectual capital is $(0.000<0.005)$. This result is obtained using banking data that is registered on the Indonesia stock exchange period 2015-2017.

From the table data, the regression equation is as follows:

ROA $=0.41+0.44 \mathrm{VAIC}-0.13 \mathrm{KI}+\mathrm{e}$

ROA: Financial performance

VAIC: Intellectual Capital

KI: Institutional ownership

$\beta=0.41$ means , constants $(\alpha)$ equal to 0.41 , if there is no increase in the Intellectual capital and Institutional ownership, then the ROA is 0.41

$\beta=0.44$ means that if Intellectual capital in a bank increases, the other variables will be constant and financial performance will increase by 0.44

$\beta=-0.13$ means that if institutional ownership increases, the other variables will remain or constant and financial performance will increase by -0.13

The higher the company in increasing intellectual capital, the higher the company's expectation for the performance of financial in the future. By looking at the overall composition the capital of intellectual supporters that influence each other will result in the bank's net income from year to year will increase which results in the trust of investors to continue to instill and use the products provided by the bank. With the Bank's attention to the Intellectual capital, the shareholders will assess that the bank will meet the interests of all stakeholders (Alim: 2018) .

The high level of institutional ownership shows that the great level of oversight by institutional investors to overcome manager's operational behavior. Institutional ownership in banking acts as amonitoring party which can indicate the company's ability to monitor management (Hery, 2014: 172-173). 


\section{Conclusions and Recommendations}

1. Intellectual capital has effects on financial performance where banks that utilize intellectual capital well tend to have good financial performance expectations and better net income.

2. The variable of Institutional Ownership has effects on financial performance in a negative direction where institutionalshareholders can monitor management performancebut they must also pay attention to minority stakeholders.

\section{Recommendations}

Based on the conclusions above, the suggestions made for the parties concerned in this research are as follows: 1. The samples of this research are banking companies that are registered in the Indonesia Stock Exchange period 2013-2017. The future research is expected to examine return on assets (ROA) in other sectors and other periods to determine the effect of other sectors.

2. The future research are expected to add control variable (SIZE) because the possibility of the companies in influencing business performance and expectation can increase the results significantly.

\section{Bibliography}

Alim, dkk. 2018. Apakah Intelectual Capital Meningkatkan Kinerja Keuangan Dan Nilai Perusahaan? (Kasus Bank Yang Terdaftar Di Bei). Jurnal Jurusan Manajemen UIN Alaudin Makassar.

Hery, 2014. Controllership Knowledge And Management Approach. Jakarta : Gramedia Widiasarana Jumingan. 2006. Analisis Laporan Keuangan. Jakarta : Bumi Aksara

Rahman Hassanudin. 2004. Managemen Fit And Proper Test. Yogyakarta : Pustaka Widyatama

Saleh Choirul dkk. Pengembangan Kompetensi Sumber Daya Aparatur. Malang : UB Press

Sin Hien \& Mariani Ida. 2017. Financial Managemen Canvas. Jakarta : PT Gramedia

Ulum Ihyaul. 2017. Intellectual Capital : Model Pengukuran, Framework Pengungkapan \& Kinerja Organisasi. Malang : Universitas Muhammadiyah Malang

Wiroso, S.E., M.B.A. 2005. Penghimpun Dana Dan Distribusi Hasil Usaha Bank Syariah. Jakarta : PT Grasindo 